УДК 347.427.5

DOI

\author{
О.О.Рубан \\ orcid.org/0000-0002-8602-0517 \\ кандидат юридичних наук, \\ асистент кафедри иивільного права № 2 \\ Національного юридичного університету імені Ярослава Мудрого
}

\title{
ОКРЕМІ АСПЕКТИ ЗАХИСТУ ПРАВ КРЕДИТОРІВ ПІД ЧАС ПРОЦЕДУРИ БАНКРУТСТВА
}

Постановка проблеми. Згідно із ч. 1 ст. 1 Цивільного кодексу (далі - ЦК) України, цивільним законодавством регулюються особисті немайнові та майнові відносини, засновані на юридичній рівності, вільному волевиявленні, майновій самостійності їхніх учасників, а отже, кредитор і боржник є рівноправними сторонами договірних відносин.

Проте в боржника є можливість застосовувати деякі інструменти для уникнення відповідальності за неналежне виконання зобов'язань [1]. Питання захисту прав кредиторів стають усе більш актуальними, а законодавство, на жаль, не може запропонувати ефективні механізми щодо їх вирішення.

Одним із досить ефективних інструментів захисту прав кредиторів може бути банкрутство. Кредитори часто стикаються з неплатоспроможністю боржників і вимушені ініціювати процедуру банкрутства. Статистика процедур банкрутства, через свою тривалість (а це в середньому приблизно чотири роки), значним чином впливає на показники нашої країни в рейтингу Doing Business, отже, на внутрішню і зовнішню інвестиційну привабливість.

Аналіз досліджень і публікацій. Питання законодавчого регулювання процедур банкрутства були предметом наукових праць, зокрема таких учених, як: Р.Г. Афанасьєв, В.В. Вітрянський, В.В. Джунь, О.П. Подцерковний, Б.М. Поляков, В.Ф. Попондопуло, М.В. Телюкіна, М.І. Тітов, Н.О. Саніахметова, І.В. Спасибо-Фатєєва, Е.В. Сгара, Г.П. Царик, Я.М. Шевченко, інших. Проте останнім часом деякі норми законодавства щодо банкрутства, зокрема щодо неплатоспроможності юридичних та фізичних осіб, зазнали істотних змін, однак деякі питання залишаються невирішеними. Отже, дослідження порушеного питання $є$ актуальним як із теоретичного, так $\mathrm{i}$ iз практичного погляду.

Виклад основного матеріалу. Захист інтересів кредиторів здійснюється шляхом ліквідації або продажу бізнесу, доки його вартість не зменшилася. Реабілітаційні процедури вводяться тільки за ініціативою кредиторів або в межах, що не суперечать їхнім інтересам. Так, згідно з Європейською конвенцією про деякі міжнародні аспекти банкрутства ETS № 136 від 5 червня 1990 р. процедура неспроможності (банкрутства) підприємств включає ліквідацію підприємства-боржника, призначення конкурсного керуючого і розподіл майна (конкурсна маса) між кредиторами [2].

3 метою забезпечення захисту кредиторів заходи запобігання та реабілітаційні заходи мають бути спрямовані на запобігання діям боржника 3 виводу активів, здійснюватись під контролем органу, наділеного відповідними повноваженнями [3].

Відповідно до положень ст. 40 Кодексу України з процедур банкрутства (далі - КУзПБ), Господарський суд має право за клопотанням сторін або учасників справи чи за своєю ініціативою вжити заходів до забезпечення вимог кредиторів для додаткового захисту їхніх прав.

Заходи щодо забезпечення вимог кредиторів діють відповідно до дня введення процедури санації і призначення керуючого санацією або до ухвалення постанови про визнання боржника банкрутом, відкриття ліквідаційної процедури і призначення ліквідатора, або до закриття провадження у спраBi.

Звернемо увагу на думку судді Житомирського апеляційного господарського суду I.O. Вечірко, яка зазначає, що "<...> залік зустрічних однорідних вимог може бути застосовано як спосіб погашення вимог кредиторів і у процедурі розпорядження майном. Проте такий залік має проводитися за пропозицією боржника чи окремих кредиторів за умови одночасного вирішення питання погашення заборгованості перед іншими конкурсними кредиторами. Задоволення вимог кредиторів здійснюється після формування конкурсної маси, яку становить усе майно боржника, у тому числі права вимоги (зокрема, дебіторська заборгованість)» $[4$, с. 80].

Відповідно до ст. 34 Закону «Про виконавче провадження» від 2 червня 2016 р. № 1404-VIII, у разі відкриття провадження у справі про банкрутство виконавець зупиняє вчинення виконавчих дій, якщо відповідно до закону на вимоги кредитора поширюється дія мораторію, запровадженого господарським судом. Вони відновлюються після усунення обставин, що стали підставою для зупинення вчинення зазначених виконавчих дій, або до розгляду питання по суті [5].

Отже, уже на стадії розпорядження майном права кредиторів захищаються за допомогою 
різноманітних засобів, зокрема і шляхом обмеження можливостей боржника самостійно розпоряджатися своїм майном.

Але під час процедури розпорядження майном боржник має право задовольняти лише ті вимоги кредиторів, на які не поширюється дія мораторію.

Протягом дії мораторію на задоволення вимог кредиторів, зокрема, забороняється стягнення на підставі виконавчих та інших документів, що містять майнові вимоги, зокрема й на предмет застави, за якими стягнення здійснюється в судовому або в позасудовому порядку відповідно до законодавства, забороняється виконання вимог, на які поширюється мораторій; не застосовується індекс інфляції за весь час прострочення виконання грошового зобов'язання тощо [6].

Задоволення забезпечених вимог кредиторів за рахунок майна боржника, яке є предметом забезпечення, здійснюється лише в межах провадження у справі про банкрутство.

Так, суди правильно визначають незаконність учинених боржником дій 3 погашення кредиторської заборгованості в період дії мораторію на задоволення вимог кредиторів. Зокрема, у постанові КГС ВС від 26 січня 2021 р. у справі № 910/19006/19 суд дійшов такого висновку: «У Кодексі України із процедур банкрутства не ототожнюються зміст та склад вимог кредитора в разі звернення із заявою про відкриття провадження у справі про банкрутство (які мають бути грошовими, однак до них не включаються неустойка (штраф, пеня) та інші фінансові санкції), зі змістом та складом вимог конкурсного кредитора, що можуть бути як грошовими, так і майновими (ч. 2 ст. 45 КУзПБ), включати неустойку (штраф, пеню) та інші фінансові санкції. У зв'язку з викладеним суд зазначив, що, ураховуючи положення ст. 41 КУзПБ та висновки в п. 8.2, заявлені ДПС до боржника кредиторські вимоги за зобов'язаннями у складі основного зобов'язання, сум штрафних санкцій та пені є вимогами конкурсного кредитора за грошовими зобов'язаннями боржника, на які поширюється дія мораторію на задоволення вимог кредиторів у розумінні ч. 1 ст. 41 Кодексу України з процедур банкрутства та за якими забороняється виконання вимог відповідно до ч. 3 цієї статті КУзПБ» [7].

Нині в Кодексі з процедур банкрутства закріплено положення, що всі кредитори, а не тільки конкурсні, можуть оскаржувати договори, укладені боржником після відкриття провадження у справі про банкрутство або укладені боржником протягом трьох років перед відкриттям провадження у справі про банкрутство, якщо такі завдали збитків боржнику чи кредиторам. У Законі України «Про відновлення платоспроможності боржника або визнання його банкрутом» [8] цей строк був обмежений одним роком.
Як зазначає С.В. Жуков, у питанні оспорювання правочинів боржника наявна правова колізія між ст. ст. 7 та 42 КУзПБ щодо форми судового рішення, яку має ухвалювати господарський суд. - рішення чи ухвалу за результатами спору про визнання недійсними будь-яких правочинів, укладених боржником, а також, що під час розгляду спорів щодо недійсності правочинів боржника ця суперечність законодавства може бути вирішена судовою практикою [9].

У Перехідних положеннях Кодексу України 3 процедур банкрутства внесено доповнення до ст. $25^{1}$ Закону України «Про фінансову реструктуризацію» і зазначено, що боржник та забезпечений кредитор за погодженням можуть установити у плані реструктуризації або мировій угоді інші умови та порядок погашення вимог забезпеченого кредитора, за умови, що вони є не гіршими для інтересів боржника, ніж ті, що встановлені цим пунктом.

Але варто зазначити, що самим КУзПБ узагалі не передбачено укладення мирової угоди під час провадження у справі про банкрутство. Можна дійти висновку, що в цьому разі господарські суди повинні керуватися нормами Господарського процесуального кодексу України, у якому цьому питанню присвячено лише ст. ст. 192 та 193 [10].

У постанові пленуму Верховного Суду України від 18 грудня 2009 р. № 15 зазначено, що «для затвердження мирової угоди у провадженні у справі про банкрутство, за умовами якої має відбутись обмін вимог кредиторів на вже емітовані боржником акції чи інші корпоративні права, належні акціонерам чи іншим суб'єктам корпоративних прав у статутному капіталі боржника, господарський суд має перевірити наявність згоди на відчуження належних їм акцій чи часток <...>» [11].

Варто врахувати, що кредиторів зазвичай кілька, тому на початку ініціатор мирової угоди повинен узгодити свої інтереси з інтересами інших кредиторів і досягти домовленості з ними, щоб мати в комітеті кредиторів більшість голосів, необхідну для ухвалення рішення про укладення мирової угоди. Крім того, варто враховувати, що кредитори, вимоги яких забезпечені заставою, повинні дати свою письмову згоду на укладення угоди, незалежно від суми вимог і від того, чи входять вони до складу комітету кредиторів, тому проєкт мирової угоди обов'язково узгоджується і 3 ними [12, с. 118-119]. Із цією позицією кореспондується твердження 0.0. Терещенко, який відзначає, що "рішення про укладення мирової угоди від імені кредиторів ухвалює комітет кредиторів більшістю голосів кредиторів - членів комітету. Воно вважається ухваленим, коли всі кредитори, вимоги яких забезпечені заставою майна боржника, висловили письмову згоду на укладення мирової угоди. Підкреслимо, що для осіб, які не дали 
згоди на укладення мирової угоди, не можуть бути встановлені умови гірші, ніж для тих, які підтримали укладення угоди» [13, с. 296].

Неврегульованість зазначеного питання дає підстави вважати, що проблема укладення мирової угоди у процедурі банкрутства відкриє широкі можливості для різноманітної неоднозначної судової практики господарським судам усіх інстанцій.

Щодо задоволення вимог кредиторів, забезпечених за рахунок майна боржника, яке є предметом забезпечення, дія мораторію припиняється автоматично після спливу 170 календарних днів із дня введення процедури розпорядження майном, якщо господарським судом протягом цього часу не було винесено постанову про визнання боржника банкрутом або ухвалу про введення процедури санації. Але якщо в період процедури санації таке майно не задіяне у виконанні плану санації боржника або є швидкозношуваним предметом чи товаром, що швидко псується, то за клопотанням забезпеченого кредитора господарський суд може ухвалити рішення про припинення дії мораторію щодо нього.

Факт ліквідації боржника за кредитним договором за наявності заборгованості боржника за цим договором, яка не була погашена у процедурі ліквідації, не є підставою для припинення договору застави (іпотеки), укладеного для забезпечення виконання кредитного договору боржником, якщо до цього заставодержателем / іпотекодержателем було реалізовано його право на звернення стягнення на передане в заставу (іпотеку) майно відповідно до положень ст. 590 ЦК України, ст. 33 Закону України «Про іпотеку».

Після закінчення строків процедури розпорядження майном, якщо не ухвалено рішення про закриття провадження у справі, відкриття ліквідаційної процедури або процедури санації, забезпечений кредитор отримує можливість за рахунок предметів іпотеки та застави погасити свою заборгованість, зокрема й поза межами справи про банкрутство.

В абз. 2 ч. 1 ст. 54 КУзПБ суду надано право визначати строк, протягом якого ліквідатор зобов'язаний здійснити ліквідацію боржника. Цей строк не може перевищувати 12 місяців.

Нин процедура санації у КУзПБ узагалі не обмежена строком.

Ще одна новела внесена в ч. 6 ст. 34 КУзПБ щодо субсидіарної відповідальності осіб, винних у банкрутстві боржника (бенефіціарні власники боржника). Кредитори мають право ініціювати, у разі невчасно поданої заяви про відкриття провадження у справі про банкротство з моменту виникнення загрози неплатоспроможності, солідарну (сумісну) відповідальність керівництва боржника за незадоволення своїх вимог.
Варто зазначити, що КУзПБ тепер не містить поняття «позаконкурсний кредитор шостої черги», а сам строк для подання заяви кредитором після публікації про відкриття провадження не є граничним. Але якщо кредитор не встиг заявити свої вимоги у встановлений законом строк, він залишиться без права голосу на зборах кредиторів.

Також забезпечений кредитор може ініціювати зняття мораторію в разі введення санації боржника, може цілком або частково відмовитись від забезпечення. Такі кредитори, відповідно до п. 2 ст. 45 КУзПБ, розглядаються як забезпечені лише в частині вартості предмета застави.

Процедура ліквідації є заключною у справі про банкрутство, вийти з неї можна лише одним шляхом - через мирову угоду. У процедурі ліквідації немає фінансового оздоровлення - тут уже реалізується майно боржника. Вона менш ефективна, ніж процедура санації, оскільки під час реалізації майнових активів боржника кредитори отримують в п'ять - десять разів менше їхньої балансової вартості. 3 іншого боку, ліквідація боржника - це крайній спосіб отримання заборгованості та її списання за бухгалтерською звітністю [14, с. 84].

Висновки. Позитивні зміни в законодавстві мають забезпечити належний рівень захищеності прав кредиторів і боржників.

Отже, можна зробити висновок, що законодавець уніс значні зміни щодо питання захисту інтересів кредиторів у справах про банкрутство. Але лише практика застосування норм нового Кодексу України з процедур банкрутства дасть відповідь на питання, наскільки захищені права кредиторів у процедурі банкрутства, яким чином кредитори матимуть можливість реалізувати свої права та захистити охоронювані законом інтереси.

Надання нормами КУзПБ конкурсним i забезпеченим кредиторам можливості впливати на формування умов продажу майна боржника, нові правила продажу майна боржника, зміна порядку звітування арбітражного керуючого про свою діяльність перед кредиторами справді сприятимуть підвищенню рівня захищеності всіх кредиторів. Отже, зроблено вагомий крок до реформування вітчизняного законодавства про банкрутство в бік прокредиторського регулювання відносин неплатоспроможності.

\section{Jimepamypa}

1. Ruban O.O., Nadon V.V., Yavor O.A. Capitalization of payments as a way to compensate the damage to life and health of an individualin case of a legal entity's bankruptcy. Financial and credit activity: problems of theory and practice. 2019. № 1. P. 515-521.

2. Європейська конвенція про деякі міжнародні аспекти банкрутства ETS № 136 від 5 червня 1990 р. URL: https://zakon.rada.gov.ua/laws/show/994_540.

3. Жуков С.В. Кодекс 3 процедур банкрутства: суддя Верховного Суду про ТОП 15 новел. 
URL: http://finbalance.com.ua/news/Kodeks-z-protsedurbankrutstva-suddya-Verkhovnoho-Sudu-pro-TOP 15-novel.

4. Вечірко І.О. Проблеми проведення розрахунків з кредиторами у процедурі розпорядження майном боржника. Санація та банкрутство : науково-практичний журнал. 2006. № 3. С. 78-81.

5. Про виконавче провадження : Закон України від 21 квітня 1999 р. Відомості Верховної Ради України. 1999. № 24. Ст. 207.

6. Кодекс України з процедур банкрутства. Відомості Верховної Ради України. 2019. № 19. Ст. 74. URL: https://zakon.rada.gov.ua/laws/show/ 2597-19\#Text.

7. Постанова КГС ВС від 26 січня 2021 р. у справі № 910/19006/19. URL: https://reyestr.court.gov.ua/ Review/94696469.

8. Про відновлення платоспроможності боржника або визнання його банкрутом : Закон України від 14 травня 1992 р. Відомості Верховної Ради Украӥни. 1992. № 31. Ст. 440.

9. Жуков С.В. Проблемні питання визнання недійсними правочинів боржника у справі про банкрутство. Застосування норм Кодексу України з процедур банкрутства : збірка наукових статей / за заг. ред. C.B. Жукова. URL: http://supreme.court.gov.ua/ userfiles/media/Jukov_Zbirka_Bankrut_v2_191007 out.pdf.

10. Господарський процесуальний кодекс України. Відомості Верховної Ради України. 1992. № 6. Ст. 56.

11. Постанова пленуму Верховного суду України від 18 грудня 2009 р. № 15. URL: http://zakon5.rada. gov.ua/laws/show/v0015700-09.

12. Бобкова А.Г., Татькова З.Ф. Правове регулювання відносин у процедурі банкрутства : навчальний посібник. Київ : Центр навчальної літератури, 2006. $152 \mathrm{c.}$

13. Терещенко 0.О. Фінансова санація та банкрутство підприємств : навчальний посібник. Київ : КНЕУ, 2000. 412 c.

14. Поляков Б.М. Право несостоятельности (банкротства) в Украине. Киев : Концерн «Видавничий дім «Iн Юре»», 2003. 440 c.

\section{Анотація}

Рубан 0. О. Окремі аспекти захисту прав кредиторів під час процедури банкрутства. - Стаття.

Статтю присвячено дослідженню різних аспектів захисту прав кредиторів під час процедури банкрутства. Розглянуто питання захисту прав і забезпечення вимог кредиторів. Проаналізовано зміни, які внесені до законодавства про неплатоспроможність (банкрутство). Зокрема норми Кодексу України з процедур банкрутства. Зазначено, що самим Кодексом України з процедур банкрутства не передбачено укладення мирової угоди під час провадження у справі про банкрутство, а отже, у такому разі господарські суди повинні керуватися нормами Господарського процесуального кодексу України. На стадії розпорядження майном права кредиторів захищаються за допомогою різноманітних засобів, зокрема і шляхом обмеження можливостей боржника самостійно розпоряджатися своїм майном. Але під час процедури розпорядження майном боржник має право задовольняти лише ті вимоги кредиторів, на які не поширюється дія мораторію. У статті визначається, що судова практика керується відповідним законодавством і правильно визначає незаконність учинених боржником дій із погашення кредиторської заборгованості в період дії мораторію на задоволення вимог кредиторів.

Кодексом України із процедур банкрутства закріплено положення, що всі кредитори, а не тільки конкурсні, можуть оскаржувати договори, укладені боржником після відкриття провадження у справі про банкрутство або укладені боржником протягом трьох років перед відкриттям провадження у справі про банкрутство, якщо такі завдали збитків боржнику чи кредиторам. Раніше в Законі України «Про відновлення платоспроможності боржника або визнання його банкрутом» цей строк був обмежений одним роком.

Доведено, що процедура ліквідації менш ефективна, ніж процедура санації, оскільки під час реалізації майнових активів боржника кредитори отримують у п'ять - десять разів менше їхньої балансової вартості. З іншого боку, ліквідація боржника - це крайній спосіб отримання заборгованості.

Ключові слова: захист прав кредиторів, процедура банкрутства, розпорядження майном, ліквідація, мирова угода.

\section{Summary}

Ruban O. O. Some aspects of protection of creditors' rights during bankruptcy proceedings. - Article.

The article is devoted to the study of various aspects of protection of creditors' rights during bankruptcy proceedings. The issues of protection of rights and securing creditors' claims are considered. The changes made to the legislation on insolvency (bankruptcy) are analyzed. In particular, the rules of the Bankruptcy Code of Ukraine. It is noted that the Bankruptcy Procedure Code of Ukraine itself does not provide for the conclusion of an amicable agreement during bankruptcy proceedings, and therefore in this case, commercial courts must be guided by the provisions of the Commercial Procedure Code of Ukraine. At the stage of disposition of property, the rights of creditors are protected by various means, including by limiting the debtor's ability to independently dispose of their property. However, during the property disposal procedure, the debtor has the right to satisfy only those creditors' claims that are not covered by the moratorium. The article stipulates that the case law is governed by the relevant legislation and correctly determines the illegality of the debtor's actions to repay accounts payable during the moratorium on satisfaction of creditors' claims.

The Bankruptcy Code of Ukraine stipulates that all creditors, not only bankruptcy, may challenge contracts entered into by the debtor after the opening of bankruptcy proceedings or concluded by the debtor within three years before the opening of bankruptcy proceedings, if such damage to the debtor or creditors. Previously, in the Law of Ukraine "On Restoration of Debtor's Solvency or Recognition of Debtor's Bankruptcy" this term was limited to one year.

It has been proven that the liquidation procedure is less effective than the rehabilitation procedure, because when selling the debtor's property assets, creditors receive five to ten times less than their book value. On the other hand, liquidation of the debtor is an extreme way of obtaining debt.

Key words: protection of creditors' rights, bankruptcy proceedings, disposition of property, liquidation, amicable settlement. 